https://doi.org/10.17816/MAJ191S1102-103

\title{
IMPACT OF AGING ON THE DEVELOPMENT OF NEUROIMMUNE DEFICIENCIES AFTER EXPERIMENTAL MILD TRAUMATIC BRAIN INJURY (TBI)
}

\author{
N.B. Serebryanaya ${ }^{1,2,3}$, S.N. Shanin ${ }^{1}$, T.A. Filatenkova ${ }^{1}$, E.E. Fomicheva ${ }^{1}$
}

${ }^{1}$ Institute of Experimental Medicine, Saint Petersburg, Russia;

${ }^{2}$ Saint Petersburg State University, Saint Petersburg, Russia;

${ }^{3}$ North-Western State Medical University named after I.I. Mechnikov, Saint Petersburg, Russia

\section{ВЛИЯНИЕ СТАРЕНИЯ НА РАЗВИТИЕ НЕЙРОИММУНЫХ НАРУШЕНИЙ ПРИ ЭКСПЕРИМЕНТАЛЬНОЙ ЧМТ ЛЕГКОЙ СТЕПЕНИ}

\author{
Н.Б. Серебряная ${ }^{1,2,3}$, С.Н. Шанин ${ }^{1}$, Т.А. Филатенкова ${ }^{1}$, Е.Е. Фомичева ${ }^{1}$ \\ ${ }^{1}$ ФГБНУ «Институт экспериментальной медицины», Санкт-Петербург; \\ ${ }^{2}$ Санкт-Петербургский Государственный Университет, Санкт-Петербург; \\ ${ }^{3}$ ФГБОУ ВО «Северо-Западный государственный медицинский университет им. И.И. Мечникова, \\ Санкт-Петербург
}

nbvma@mail.ru

Patient's age affects the course of posttraumatic inflammation and recovery after TBI. The goal of the research was to identify the differences in neuroimmune deficiencies in young and old animals after experimental TBI. The research was carried out using male Wistar rats aged 3 and 18 months. Mild TBI was caused by weight drop TBI model. A group of animals was injected abdominally with $30 \mathrm{mkg} / \mathrm{kg}$ recombinant human interleukin-2 (Ronkoleukin, Biotech) daily for three days, starting 72 hours after TBI. The control group consisted of intact animals and rats who did not receive rIL-2 prior to TBI ( $n=5$ for both groups). The results obtained have shown that old animals after mild TBI had different testosterone and proliferative activity levels than the young ones; the injection of rIL-2 led to an increase in neurotrophic factors (testosterone and BDNF) without causing additional activation of lymphocytes.

Keywords: experimental traumatic brain injury; aging; recombinant human interleukin-2; BDNF; testosterone, lymphocyte proliferative activity.

Старение влияет на течение посттравматического воспаления и восстановление после ЧМТ. Целью исследования было определение различий нейроиммунных нарушений, развивающихся у молодых и старых животных при экспериментальной ЧМТ. Работа выполнена на крысах-самцах породы Wistar в возрасте 3 и 18 мес. Использовали модель «падающего груза», воспроизводя ЧМТ легкой степени. Группе животных вводили рекомбинантный человеческий интерлейкин-2 (ронколейкин) («БИОТЕХ», РФ) ежедневно, всего 3 инъекции по 30 мкг/кг, начиная с 72 часов после ЧМТ. Группами сравнения были интактные животные и животные, получавшие ЧМТ без введения rIL-2 (во всех группах $n=5$ ). Полученные результаты свидетельствуют, что старые животные после ЧМТ отличались от молодых более низкими показателями концентрации тестостерона и пролиферативной активности лимфоцитов, а введение рИЛ-2 обеспечивало повышение уровня нейротропных факторов (тестостерона и BDNF), не вызывая дополнительной активации лимфоцитов.

Ключевые слова: экспериментальная черепно-мозговая травма; старение; рекомбинантный человеческий интерлейкин-2; BDNF; тестостерон; пролиферативная активность лимфоцитов.

Introduction. Patient's age significantly affects the course of traumatic process and recovery after TBI. Senior people usually show higher morbidity and mortality rate after TBI, as well as a slower and poorer functional recovery than younger people. Aging leads to a chronic low-active internal inflammation called inflammaging. It is a result of the increased number of senescence cells that have senescence-associated secretory phenotype. The immune system is involved in immune surveillance of the brain where T-lymphocytes monitor the integrity and operation of neutrons [1]. The condition of the endocrine system is affected by aging and the damage to pituitary gland and hypo- thalamus after TBI [2]. Brain healing after TBI is stimulated by various mechanisms, including secretion of neurotrophic factors, such as BDNF; however, BDNF levels in the blood serum and brain decrease with age [3], which affects the recovery after TBI. The goal of the research was to identify the differences in neuroimmune deficiencies in young and old animals after an experimental TBI.

Materials and methods. The research was carried out using male Wistar rats aged 3 and 18 months. Mild TBI was caused by weight drop TBI model. A group of rats was injected abdominally with $30 \mathrm{mkg} / \mathrm{kg}$ recombinant human interleukin-2 (Ronkoleukin, Biotech) daily for three days, start- 
Parameters of young and old rats before and after experimental mild TBI

\begin{tabular}{|l|c|c|c|c|c|c|}
\hline \multirow{2}{*}{} & \multicolumn{2}{|c|}{ Intact animals } & \multicolumn{2}{c|}{$7^{\text {th }}$ day after TBI } & \multicolumn{2}{c|}{+ rlL-2, $7^{\text {th }}$ day after TBI } \\
\cline { 2 - 7 } & Young & Old & Young & Old & Young & Old \\
\hline Testosterone $(\mathrm{ng} / \mathrm{ml})$ & $1.95 \pm 0.30$ & $1.82 \pm 0.34$ & $3.52 \pm 0.29^{*}$ & $1.01 \pm 0.57^{!}$ & $7.8 \pm 1.08^{* \#}$ & $3.46 \pm 0.91^{* \# !}$ \\
\hline BDNF $(\mathrm{pg} / \mathrm{ml})$ & $4.01 \pm 0.66$ & $3.09 \pm 0.78$ & $7.54 \pm 0.66^{*}$ & $8.27 \pm 1.52^{*}$ & $17.04 \pm 2.3^{* \#}$ & $10.1 \pm 2.84^{* !}$ \\
\hline NK-cells cytotoxicity (\%) & $18.1 \pm 3.4$ & $18.2 \pm 2.4$ & $27.5 \pm 3.6^{*}$ & $24.3 \pm 3.0^{*}$ & $26.4 \pm 4.2^{*}$ & $22.7 \pm 3.9$ \\
\hline LBT (stimulation index) & $1.57 \pm 0.68$ & $1.48 \pm 1.01$ & $3.73 \pm 1.21^{*}$ & $1.95 \pm 0.42^{!}$ & $2.72 \pm 0.62$ & $1.99 \pm 1.08$ \\
\hline
\end{tabular}

Note. ${ }^{*} p<0.05$ compared to intact animals; ${ }^{*} p<0.05$ compared to animals on the $7^{\text {th }}$ day after TBI; ! $p<0.05$ compared to young animals.

ing 72 hours after TBI. The control group consisted of intact rats and rats who didn't receive rIL-2 after TBI ( $n=5$ for both groups). The concentration of BDNF and testosterone in the blood was measured using ELISA. The cytotoxic activity of NK-cells was estimated by their ability to lyse cells of the K-562 line. The proliferative activity of splenocytes was estimated by the activity of lymphocyte blast transformation (LBT) in response to Con A exposure.

Results and discussion. The data in Table 1 show that neither young, nor old rats had significant differences in BDNF and testosterone levels. Young rats reacted to TBI with verifiable increase in testosterone production; in old rats, a rapid distress in testosterone production was recorded. Both young and old rats had increased BDNF levels after TBI. The animals injected with rIL-2 after
TBI had a significant increase in testosterone and BDNF levels. It has been shown that a decrease in the BDNF serum level after TBI correlated with the gravity of injury. Therefore, the presented data confirm that TBI was mild [4].

Activity of NK-cells in young and old rats after TBI rose verifiably while the proliferative activity of lymphocytes increased only in young rats. The injection of rIL-2 did not lead to further increase in these parameters, which may have been due to a low dosage. The results obtained have shown that old animals after mild TBI had different testosterone and proliferative activity levels than the young ones; the injection of rIL-2 led to an increase in neurotrophic factors (testosterone and BDNF) without causing additional activation of lymphocytes.

\section{References}

1. Cose S, Brammer C, Khanna KM, et al. Evidence that a significant number of naive T cells enter nonlymphoid organs as part of a normal migratory pathway. Eur J Immunol. 2006;36(6):1423-33.

2. Richmond E, Rogol AD. Traumatic brain injury: endocrine consequences in children and adults. Endocrine. 2014;45(1):3-8. https://doi.org/10.1007/s12020-013-0049-1.

3. Erickson KI, Prakash RS, Voss MW, et. al. Brain-derived neurotrophic factor is associated with age-related decline in hippocampal volume. J Neurosci. 2010;30(15):5368-75.

4. Kalish H, Phillips TM. Analysis of neurotrophins in human serum by immunoaffinity capillary electrophoresis (ICE) following traumatic head injury. J Chromatogr B Analyt Technol Biomed Life Sci. 2010;878(2):194-200. 